\title{
Aquatic macroinvertebrate colonization of artificial substrates in low-order streams
}

\author{
Luciene Aparecida Leite-Rossi * \\ Gisele Nunes Rodrigues \\ Susana Trivinho-Strixino \\ Universidade Federal de São Carlos, Campus de São Carlos \\ Rodovia Washington Luís, km 235 - SP-310, CEP 13565-905, São Carlos, SP, Brasil \\ * Autor para correspondência \\ luciene.rossi@yahoo.com.br
}

Submetido em 29/08/2014

Aceito para publicação em 17/04/2015

\section{Resumo}

Colonização de substratos artificiais por macroinvertebrados aquáticos em córregos de baixa ordem. A natureza do substrato é um dos fatores que determina a presença e o estabelecimento da biota bentônica nos ecossistemas aquáticos. A colonização de substratos artificiais por macroinvertebrados em avaliações das comunidades tem sido frequentemente utilizada como ferramenta pelas facilidades operacionais que oferece. O presente estudo teve por finalidade verificar se há, ou não, seletividade da macrofauna por diferentes tipos de substratos artificiais. Recipientes de colonização contendo diferentes substratos foram imersos em três pequenos córregos da região de São Carlos - SP por 30 dias. Para avaliar a seletividade de cada tipo de substrato uma comparação foi feita entre a fauna colonizadora e a fauna residente em cada córrego. A análise dos dados indicou que todos os substratos artificiais utilizados apresentaram diferentes seletividades nos córregos estudados. Os resultados apontam para a necessidade de prévio conhecimento das características do corpo d'água objeto de estudo (por ex. tipo de substratos do leito, vegetação do entorno, etc.) para a escolha do tipo de substrato artificial que será mais bem colonizado por determinado grupo de macroinvertebrados.

Palavras-chave: Colonização; Insetos Aquáticos; Sistemas Lóticos; Substratos artificiais

\section{Abstract}

One of the factors that determine the presence and establishment of the benthic biota in aquatic ecosystems is the nature of the available substrate. The colonization of artificial substrates for macroinvertebrates has often been used as a tool in environmental assessments by operating facilities it provides. The present study aimed to determine whether or not macrofauna exhibit selectivity for different types of artificial substrates. Colonization recipients containing different substrates were immersed in three small streams in the region of São Carlos, São Paulo, for 30 days. To evaluate selectivity for each substrate type, a comparison was made between the colonizing and resident fauna in each stream. Data analysis indicated that macroinvertebrate fauna exhibited selectivity for different artificial substrate types in the streams studied. These results point to the need for knowledge of water body characteristics prior to study (e. g., types of substrates in stream beds and surrounding vegetation, etc.) in order to choose the types of artificial substrates that are better colonized by specific groups of macroinvertebrates.

Key words: Aquatic insects; Artificial substrates; Colonization; Lotic systems 


\section{Introduction}

The type of substrate present in river and stream beds is one of the factors that determines the nature and structure of the resident benthic community (RIERADEVAL et al., 1999; MOLOZZI et al., 2011). Colonization experiments have been used in river and stream biomonitoring programs (OLOMUKORO; TOCHUKWU, 2006), and analyses of lotic system communities with varying habitat characteristics or under the influence of human impacts have been conducted through experiments measuring colonization on both natural and artificial substrates (CARVALHO; UIEDA, 2004; JANKE; TRIVINHO-STRIXINO, 2007; SOUZA et al., 2008, PEREIRA et al., 2010; LEITE-ROSSI; TRIVINHO-STRIXINO, 2012). Among the substrates commonly used are mineral, organic, and manufactured material (BENÔIT et al., 1998; CZERNIAWSKA-KUSZA, 2004; RIBEIRO; UIEDA, 2005; CORREIA; TRIVINHO-STRIXINO, 2005; OLOMUKORU; TOCHUKWU, 2006; SAITO; MAZÃO, 2012).

The use of artificial substrates for experimental purposes has the advantage of allowing more accurate data collection via standardizing the sampling area and the substrate material, as well as the time of the initial colonization process (SANSEVERINO; NESSIMIAN, 1998; CARVALHO; UIEDA, 2004). Furthermore, this technique offers low economic cost, rapid sample processing in the laboratory, and the ability to obtain samples in environments where data collection is difficult for conventional samplers (WANTZEN; PINTO-SILVA, 2006). However, there is little knowledge of colonization dynamics and the ideal time of exposure, and artificial samples are often subject to losses due to flooding and vandalism (ALVES; STRIXINO, 2003; SOUZA et al., 2008). In addition, the selectivity that artificial substrates promote can bias the sampling to the particular taxonomic groups with affinity toward them (MACKAY, 1992; ORTELI; LACHAVANNE, 1995).

The strong attraction or preference of some macroinvertebrate groups for certain substrates may be related to resource use; they can feed on the substrates, search them for prey, or use them as a place of refuge or settlement, and interactions between these factors are also possible (DUDGEON; WU, 1999; GRAÇA, 2001). Mining and shredding groups, for example, are easily found in colonization experiments that use plant detritus as substrate (CLAPCOTT; BUNN, 2003; GONÇALVES et al., 2012; LEITE-ROSSI; TRIVINHO-STRIXINO, 2012). Organisms such as Simuliidae larvae and pupae have a habit of attaching to hard substrates, and are found only in experiments using material such as stones, strips of polyethylene, and expanded clay (PEPINELLI; TRIVINHO-STRIXINO, 2002). These observations are consistent with studies reporting a strong relationship between the distribution of macroinvertebrates in streams and the natural microhabitats formed (FENOGLIO et al., 2002; CZERNIAWSKA-KUSZA, 2004).

The goal of this study was to describe and evaluate the colonization of different substrates in three loworder streams, comparing the colonizing fauna with the resident community at each site. The main goal was to investigate whether macroinvertebrates exhibit substrate selectivity in this these environments. Among the substrates used were two inorganic types (gravel and expanded clay), and three organics (a kind of vegetable sponge known as loofah, plant detritus, and pine bracts). The streams selected are located in areas with extensive riparian vegetation cover and thus stream beds contain large amounts of leaves and branches. We hypothesized that the artificial substrate containing vegetation debris will present lower macroinvertebrate selectivity.

\section{Material and Methods}

\section{Study sites}

Three stream sites were chosen in areas of preserved vegetation in the region of São Carlos, São Paulo, Brazil. All streams have sandy substrate, covered with plant debris in different stages of decomposition. The Canchim stream (21 $\left.{ }^{\circ} 54^{\prime} \mathrm{S}, 4^{\circ} 58^{\prime} \mathrm{W}\right)$ is a second order stream with gravel and rock fragments on the bed. The surface water velocity is near $0.25 \mathrm{~m} . \mathrm{s}^{-1}$, with a depth of $0.12 \mathrm{~m}$ and maximum width of $1.1 \mathrm{~m}$ (PAULA; FONSECA-GESSNER, 2010). The Espraiado stream $\left(21^{\circ} 53^{\prime} \mathrm{S}, 47^{\circ} 52^{\prime} \mathrm{W}\right)$ has a slightly sinuous area near the 
mouth that is relatively narrow, with width and depth not exceeding $1 \mathrm{~m}$, and current velocity less than $1.5 \mathrm{~m} . \mathrm{s}^{-1}$ (CORBI; TRIVINHO-STRIXINO, 2008). The Fazzari stream $\left(21^{\circ} 58^{\prime} \mathrm{S}, 47^{\circ} 53^{\prime} \mathrm{W}\right)$ has a velocity of $0.28 \mathrm{~m} . \mathrm{s}^{-1}$, and a maximum depth and width of $0.60 \mathrm{~m}$ and $1.50 \mathrm{~m}$, respectively (ROQUE et al., 2005).

\section{Experimental procedures}

The experiment took place over the dry season, using previously perforated cylindrical polyethylene bottles ( $\sim 230$ holes; $\varnothing=5 \mathrm{~mm}, 75 \mathrm{~mm}$ diam x 138 $\mathrm{mm}$ height, $500 \mathrm{~mL}$ ) as colonization artifacts. Three colonization containers were completely filled with five types of substrate (Figure 1): gravel, expanded clay, plant detritus, loofah sponge (Luffa sp.) and pine bracts, for a total of 15 samples per stream. The gravel used was similar to small crystals $(\sim 5 \mathrm{~mm} x$ $3 \mathrm{~mm}$ ) used for fish aquarium substrates. The expanded clay is a small sphere $(\varnothing=\sim 20 \mathrm{~mm})$, and the detritus consisted of random leaves and small branches (70:30 leaves:branches). The loofah plant has a format similar to the container in which it was placed into. Only the bracts were used from pinecones, which were removed from the body of the strobilus. The containers were placed on stream beds at a distance of $1 \mathrm{~m}$ between them, tethered using bricks. Containers remained for 30 days prior to sampling, a period of time considered ideal for colonization by macroinvertebrates (STOCKLEY et al., 1998). Additionally, three samples of natural substrate were taken from each stream using a hand net D ( $\varnothing=0.25 \mathrm{~mm})$. This scan covered a stretch of $2 \mathrm{~m}$, for
1 minute, and was carried out in order to explore the various natural stream habitats.

\section{Data collection}

Collected samples were washed in the laboratory using a $0.25 \mathrm{~mm}$ mesh sieve. For better preservation, Oligochaeta were placed in vials containing 4\% formaldehyde. The retained material was then sorted on an illuminated tray and preserved in $70 \%$ ethanol. The specimens were examined under a stereomicroscope and identified to the lowest possible taxonomic level. Identification was carried out using specific literature (BRINKHURST; MARCHESE, 1989; NIESER; MELO, 1997; DOMÍNGUEZ; FERNANDEZ, 2004; COSTA et al., 2004; PES et al., 2005; DOMÍNGUEZ et al., 2006, LECCI; FROEHLICH, 2007; PASSOS et al., 2007; TRIVINHO-STRIXINO, 2014).

\section{Data analysis}

The macroinvertebrate fauna were analyzed according to richness, abundance and dominance according to the Kownacki dominance index (KOWNACKI, 1971).

First, in order to verify substrate selectivity among macroinvertebrates a Permutional Multivariate Analysis of Variance (PERMANOVA) was performed with 10,000 permutations, and Bray-Curtis dissimilarity was measured considering the three streams as replicates using abundance as a response variable. To evaluate differences in the colonization among the streams,

FIGURE 1: Substrates used in the experiment of colonization: 1 - gravel; 2 - expanded clay; 3 - organic detritus; 4 - loofah sponge; 5 - pine bracts.

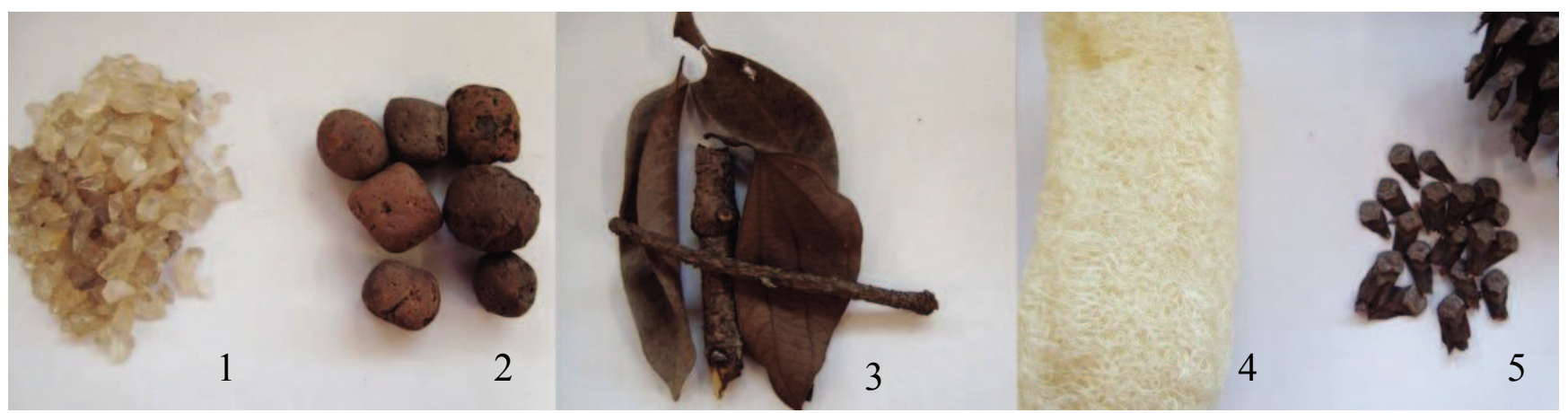


we tested two Generalized Linear Models (GLM) using richness and abundance as response variables, and a Detrended Correspondence Analysis (DCA) using abundance as response variable. Streams were considered individually in these analyses. To verify differences among DCA clusters, we performed an Analysis of Variance (ANOVA) with data shift from the first axis. To test the prediction that the plant detritus is more similar to natural bed substrate, we performed a one-way ANOVA using species richness per substrate, and considering the three streams as replicates.

\section{Results}

We identified 5205 macroinvertebrates in total from 16 families and 68 taxa. Tables 1-3 show the most dominant taxa. With the exception of Canchim stream, detritus was the artificial substrate with the greatest number of individuals and taxa closest to natural bed substrate, gathering $51 \%$ and $46 \%$ of the total individuals and $56 \%$ and $59 \%$ of the taxa in Espraiado and Fazzari streams, respectively; detritus grouped only $23 \%$ of the macrofauna, and $63 \%$ of the taxa of the Canchim stream. The most prevalent group (except Chironomidae) was the ephemerid larvae Askola and Miroculis, the first one present in almost all collections of the Canchim and Espraiado streams and the latter in Espraiado and Fazzari streams. The flatworm Girardia was also prevalent in all streams, but showed higher dominance index on artificial substrates. Other taxa were also dominant in most substrates, but prevailed only in one or another stream; for example: Laccophillus in the Espraiado stream, Barypenthus in the Canchim stream and Glossiphoniidae in the Fazzari stream. Some taxa stood out on certain types of substrates. For example, in the Canchim stream Guajirolus were found on loofah, Cernotina and Oecetis on clay, Kempnya and Cyrnelos on gravel, Naididae on detritus, Amphipoda on gravel and loofah; Kempnya were found on clay in the Fazzari, and Cyrnelos on clay in the Espraiado.

Chironomidae larvae were the most representative taxa (30) in all streams (Canchim $-62 \%$ of total individuals; Fazzari - 68\%; Espraiado - 56\%). The dominance analysis showed that each taxa presented a different distribution. Among the tribe Tanytarsini, the larvae of Caladomyia and Tanytarsus were the most abundant in almost all streams and substrates. Other taxa

TABLE 1: Kownacki dominance index of the most dominant macroinvertebrate taxa in each artificial substrate and natural bed substrate in Canchim stream. Bold values indicate dominance $>5 \%$.

\begin{tabular}{lcccccc}
\hline \multirow{2}{*}{\multicolumn{1}{c}{ Taxa }} & \multicolumn{3}{c}{ Artificial Substrate } & Natural bed \\
\cline { 2 - 5 } & Detritus & Loofah & Gravel & Pine bracts & Clay & substrate \\
\hline Girardia Ball 1974 & 2.17 & 1.82 & 4.53 & $\mathbf{8 . 2 3}$ & 2.11 & 0.89 \\
Naididae & $\mathbf{1 5 . 8 4}$ & - & - & - & 0.26 & 4.86 \\
Askola Peters 1969 & 4.58 & 0.72 & $\mathbf{5 . 6 6}$ & 1.84 & 1.06 & 0.64 \\
Miroculis Edmunds 1963 & - & - & - & - & - & $\mathbf{6 . 8 4}$ \\
Barypenthus Burmeister 1839 & 0.1 & 4.89 & 1.01 & - & 1.06 & $\mathbf{5 . 3 7}$ \\
Ablabesmyia Johannsen 1905 & 2.48 & 0.73 & 0.12 & 0.82 & 0.26 & $\mathbf{6 . 0 1}$ \\
Caladomyia Säwedall 1981 & $\mathbf{5 . 9}$ & $\mathbf{9 . 7 8}$ & $\mathbf{9 . 0 6}$ & $\mathbf{6 . 7 1}$ & $\mathbf{1 3 . 1 9}$ & 4.5 \\
Labrundinia Fittkau 1962 & $\mathbf{1 3 . 6 6}$ & $\mathbf{1 1 . 4 1}$ & 1.01 & 2.45 & 4.72 & 3.67 \\
Larsia Fittkau 1962 & 4.35 & 2.55 & 4.53 & $\mathbf{6 . 4}$ & 1.58 & 3.01 \\
Nanocladius Kieffer 1913 & 0.62 & $\mathbf{6 . 5 2}$ & 0.12 & 0.82 & 3.94 & 0.37 \\
Pentaneura Phillipi 1865 & 3.54 & $\mathbf{7 . 6 1}$ & $\mathbf{7 . 9 2}$ & $\mathbf{5 . 1 8}$ & 2.11 & 1.92 \\
Phaenopsectra Kieffer 1921 & $\mathbf{9 . 9 4}$ & $\mathbf{5 . 4 3}$ & 0.12 & $\mathbf{7 . 0 1}$ & $\mathbf{9 . 5}$ & 2.24 \\
Rheotanytarsus Thienemann Bause 1913 & 0.62 & - & $\mathbf{1 2 . 4 5}$ & $\mathbf{5 . 4 9}$ & 2.64 & 0.02 \\
Stempellinella Brundin 1947 & 4.35 & $\mathbf{5 . 9 8}$ & - & 2.13 & - & 0.68 \\
Tanytarsus v. d. Wulp 1874 & $\mathbf{1 3 . 0 4}$ & $\mathbf{1 3 . 0 4}$ & $\mathbf{3 3 . 9 6}$ & $\mathbf{3 2 . 3 2}$ & $\mathbf{1 5 . 3}$ & 3.01 \\
\hline
\end{tabular}


from this tribe were insignificant except Rheotanytarsus and Stempellinella, which were dominant in some of the artificial substrates in the Canchim stream. Among the various representatives of the tribe Chironomini, two taxa of similar life habits (mainly shredders), Phaenopsectra and Endotribelos, showed different distributions on plant-based substrates, the former being dominant in Canchim stream and the second in the Espraiado and Fazzari streams. Tanypodinae larvae (i.e., Ablabesmyia, Labrundinia, Larsia and Pentaneura) showed no specific preference for any substrate type.

The PERMANOVA indicated that taxa exhibited intrinsic selectivity for all artificial substrates used in this study, since none of the substrate types contained fauna representative of the resident community $(\mathrm{F}=14.47$; $\mathrm{p}=0.004)$. The GLMs indicated significant differences in richness $\left(\mathrm{F}_{3.15}=4.87 ; \mathrm{p}<0.001\right)$ between different substrate types and natural bed substrate (highest values) for each stream. The DCA showed significant clusters $\left(\mathrm{F}_{6.26}=12.09 ; \mathrm{p}<0.001\right)$ in relation to stream. The natural bed substrate samples were not very distant from each other, particularly between Espraiado and Fazzari streams, indicating some similarity between the resident fauna of these streams. This was not verified with the different substrate types. This result suggests that the resident macrofauna colonized the artificial substrates in a particular way in each stream (Figure 2).

FIGURE 2: DCA analysis grouping the macroinvertebrate fauna on different artificial and natural bed substrate in Canchim, Espraiado and Fazzari streams.

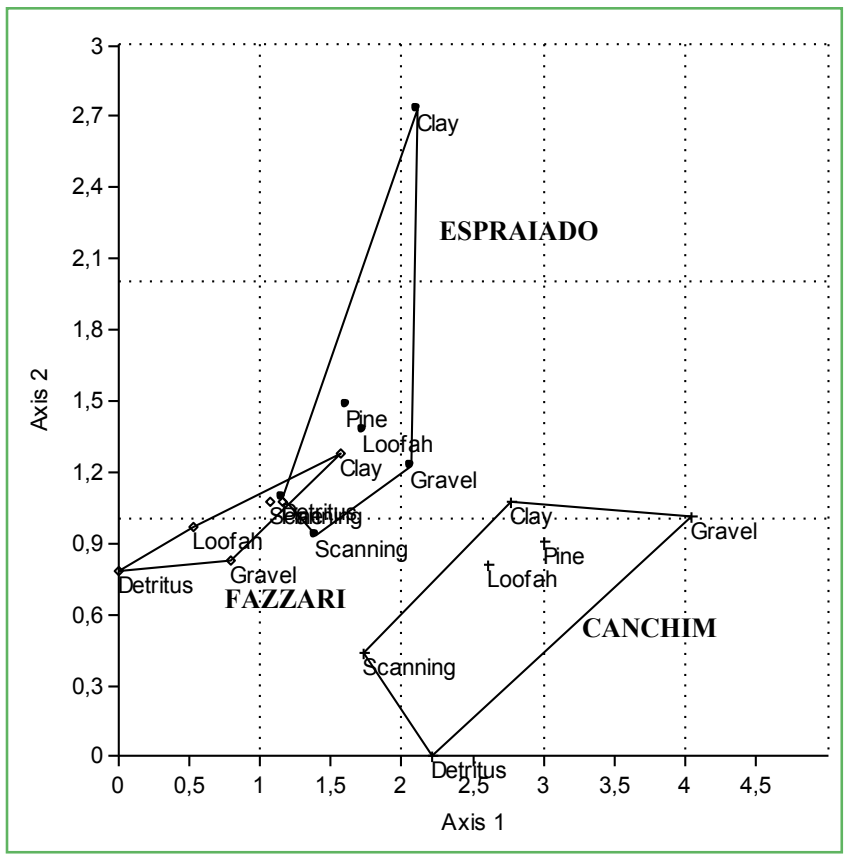

TABLE 2: Kownacki dominance index for macroinvertebrate taxa in artificial and natural bed substrate in Espraiado stream. Bold values indicate dominance $>5 \%$.

\begin{tabular}{lcccccc}
\hline \multirow{2}{*}{ Taxa } & \multicolumn{5}{c}{ Artificial Substrate } & Natural bed \\
\cline { 2 - 5 } & Detritus & Loofah & Gravel & Pine bracts & Clay & substrate \\
\hline Girardia Ball 1974 & 3.64 & 3.24 & $\mathbf{1 5 . 2 9}$ & 0.2 & 2.36 & 0.7 \\
Ostracoda & - & - & - & 1.23 & - & $\mathbf{5 . 4 5}$ \\
Askola Peters 1969 & 1.36 & 4.84 & $\mathbf{1 7 . 6 5}$ & $\mathbf{7 . 3 6}$ & - & 1.57 \\
Miroculis Edmunds 1963 & $\mathbf{2 7 . 5 3}$ & $\mathbf{1 7 . 2}$ & $\mathbf{3 2 . 9 4}$ & $\mathbf{3 1 . 9}$ & 0.79 & $\mathbf{1 5 . 5 8}$ \\
Laccophilus Leach 1815 & 4.05 & $\mathbf{5 . 3 8}$ & 0.39 & 3.68 & - & 2.34 \\
Cyrnellus Banks 1913 & - & 0.72 & - & - & $\mathbf{6 . 3 8}$ & 1.22 \\
Ablabesmyia Johannsen 1905 & 3.64 & $\mathbf{6 . 4 5}$ & 1.58 & 3.07 & 0.79 & $\mathbf{7 . 5 3}$ \\
Caladomyia Säwedall 1981 & $\mathbf{6 . 7 8}$ & $\mathbf{2 4 . 7 3}$ & $\mathbf{7 . 8 8}$ & $\mathbf{2 0 . 2 5}$ & $\mathbf{6 4 . 2 9}$ & $\mathbf{1 3 . 7 7}$ \\
Corynoneura Winnertz 1846 & 1.09 & 1.61 & $\mathbf{5 . 8 8}$ & 1.01 & - & - \\
Endotribelos Grodhaus 1987 & $\mathbf{1 5 . 7 9}$ & 1.08 & - & - & - & - \\
Labrundinia Fittkau 1962 & $\mathbf{1 6 . 1 9}$ & $\mathbf{1 0 . 2 2}$ & 3.53 & $\mathbf{7 . 4}$ & - & - \\
Larsia Fittkau 1962 & 1.62 & 1.44 & 0.39 & 0.82 & 3.19 & $\mathbf{1 1 . 6 9}$ \\
Pentaneura Phillipi 1865 & 1.63 & $\mathbf{1 7 . 7 4}$ & 3.53 & 0.82 & 0.79 & 1.82 \\
\hline
\end{tabular}


TABLE 3: Kownacki dominance index for macroinvertebrate taxa in artificial and natural bed substrate in Fazzari stream. Bold values indicate dominance $>5 \%$.

\begin{tabular}{|c|c|c|c|c|c|c|}
\hline \multirow{2}{*}{ Taxa } & \multicolumn{5}{|c|}{ Substrate } & \multirow{2}{*}{$\begin{array}{c}\text { Natural bed } \\
\text { substrate }\end{array}$} \\
\hline & Detritus & Loofah & Gravel & Pine bracts & Clay & \\
\hline Glossiphoniidae & 5.92 & - & 0.63 & 1.09 & 2.75 & 0.12 \\
\hline Naididae & - & 6.84 & 0.63 & - & - & 0.9 \\
\hline Hydracarina & - & - & 36.54 & 1.63 & - & 11.25 \\
\hline Miroculis Edmunds 1963 & 0.11 & 12.24 & - & 17.89 & 2.75 & 12.89 \\
\hline Laccophilus Leach 1815 & - & - & 11.6 & - & - & - \\
\hline Ablabesmyia Johannsen 1905 & 10.45 & 27.21 & 11.6 & 6.54 & - & 18.51 \\
\hline Caladomyia Säwedall 1981 & 0.7 & 4.08 & 3.87 & 6.5 & 11.17 & 15.25 \\
\hline Corynoneura Winnertz 1846 & 0.93 & - & 1.27 & 18.7 & - & 1.09 \\
\hline Endotribelos Grodhaus 1987 & 62.02 & 23.13 & 0.63 & 2.18 & 2.75 & 0.85 \\
\hline Labrundinia Fittkau 1962 & 1.4 & 9.52 & - & 3.27 & - & 6.35 \\
\hline Pentaneura Phillipi 1865 & 2.44 & 5.44 & 0.63 & 4.9 & 2.75 & 1.81 \\
\hline Tanytarsus v. d. Wulp 1874 & 2.57 & 5.44 & 2.58 & 10.57 & 27.92 & 5.26 \\
\hline
\end{tabular}

One-way ANOVA indicated that richness on artificial substrates was lower than for natural bed substrate $\left(\mathrm{F}_{5.17}=33.4 ; \mathrm{p}<0.001\right)$. The organic artificial substrates showed greater macroinvertebrate richness than inorganic substrates in Espraiado and Fazzari streams; in Canchim stream this result was not observed (Figure 3).

\section{Discussion}

The benthic macrofauna living in small streams generally display intimate relationships with the natural substrate (FENOGLIO et al., 2002; CZERNIAWSKAKUSZA, 2004) and some taxa show clear selectivity for certain types of substrates. For example, Phylloicus

FIGURE 3: Mean overall resident macroinvertebrate richness (dark green columns), and richness on individual organic (light green columns) and inorganic (green columns) artificial substrates.

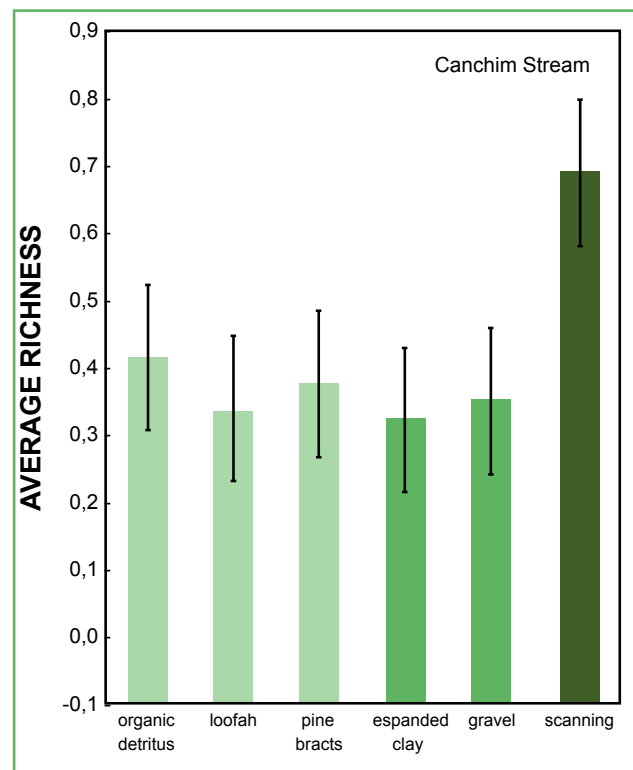

Revista Biotemas, 28 (3), setembro de 2015
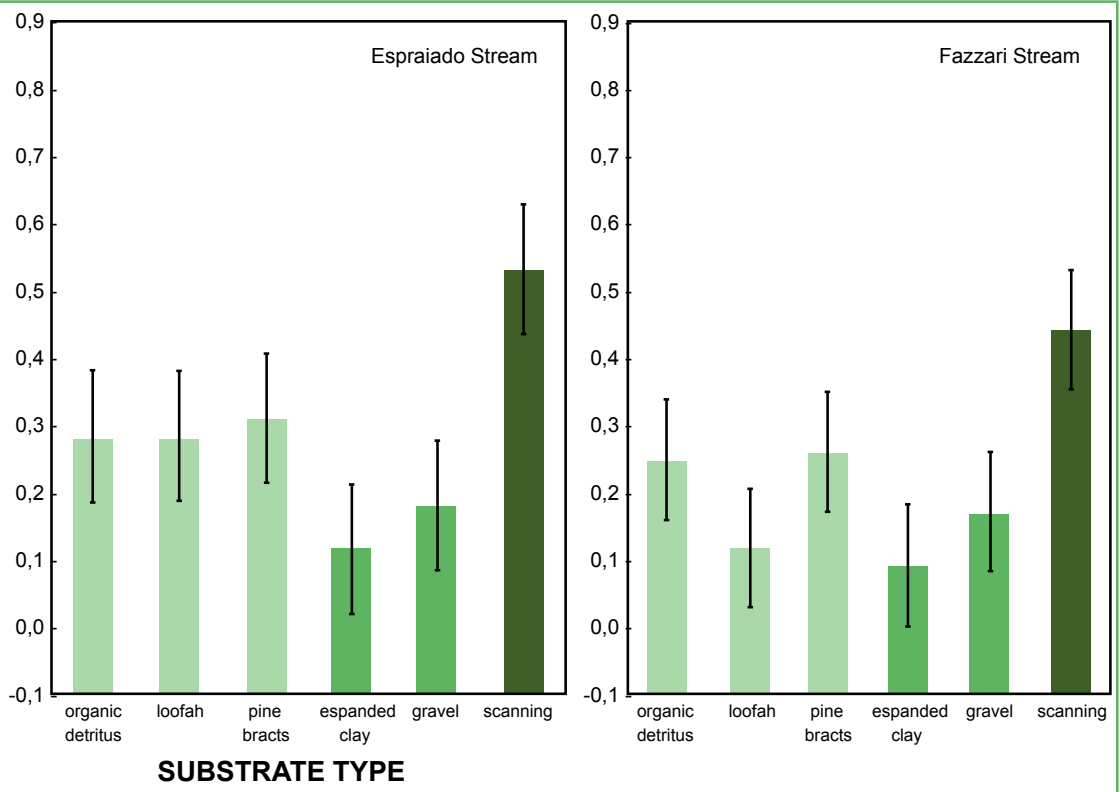
and Stenochironomus usually present clear association with submerged trunks and leaves (BORKENT, 1984; TRIVINHO-STRIXINO; STRIXINO, 1998; RINCÓN; MARTÍNEZ, 2006; VALENTE-NETO et al., 2015). Thus, the nature of stream bed material may be an important determining factor of macrobenthic community structure (BEISEL et al., 2000; RINELLA; FEMINELLA, 2005) and may indirectly define the colonization of artificial substrates.

The artificial substrates tested in this experiment revealed differential selectivity among taxa according to stream. For example, the different distribution of the two mayflies Askola and Miroculis observed in our study may be related to different preferences. The particular traits of the different taxa and consequently, the faunal richness in each substrate, varied according to the stream, possibly by the adjustment of fauna to the natural substrate type already present in the streams. We observed higher faunal richness and abundance in organic substrates than in the other artificial substrates in Espraiado and Fazzari streams, in which the bottom stream beds are formed by leaves, trunks and branches. The Canchim stream contains gravel and rock fragments in the stream bed in addition to organic substrates, and richness and abundance was similar on all artificial substrates at this site. It is also known that there is a relationship between the fauna and microhabitats formed in streams (FENOGLIO et al., 2002; CZERNIAWSKAKUSZA, 2004), and the addition of a resource may not be attractive to the local fauna.

Caution is needed when using artificial substrates to characterize environments due to their powerful selectivity (MACKAY, 1992; ORTELI; LACHAVANNE, 1995) and given the possibility of being unattractive to local wildlife. The selectivity power of an artificial substrate may be used as tool only by expert researchers to obtain particular groups of macroinvertebrates, for example, the collection of Endotribelos species (ROQUE; TRIVINHO-STRIXINO, 2008). Prior knowledge of the faunal habits and the features of the stream is thus necessary for selection the best type of artificial substrate.

Although chironomid larvae are often neglected in ecological studies or generally addressed as a single group, it is interesting to highlight the richness and abundance of this group in our experiment. This is explained by its dominance in freshwater environments compared to other aquatic insects (ARMITAGE et al., 1995). According to Carvalho and Uieda (2004), chironimidae presents low selectivity for available resources in the environment, being characterized as generalist organisms. In our experiment, Tanytarsus, Caladomyia and Phaenopsectra larvae exhibited this behavior, being dominant on several different types of substrates. As a megadiverse family, different taxa may also colonize particular substrates. For example, the larvae of the already cited Endotribelos, considered shredders of dead plant material (ROQUE et al., 2005; RAMSEYER; MARCHESE, 2009), were found more frequently and exhibited great affinity for detritus substrate compared to natural bed substrate. Other shredder larvae such as Phaenopsectra were found colonizing different artificial substrates in Canchim stream. This may be an indicative of the plasticity of the family Chironomidae, which can also obtain food as collectors from different organic or mineral substrates. On the other hand, the predator group (Ablabesmyia, Labrundinia, Larsia and Pentaneura) showed no specific preference for substrate type despite the fact that artificial substrates can potentially serve as traps for prey, aiding in their predation.

In summary, all artificial substrates used in our experiment were shown to be subject to selection by resident macroinvertebrate taxa. Furthermore, the hypothesis that the plant detritus substrate would be similar to the natural bed substrate was not confirmed. This is likely explained by environmental heterogeneity, with streams composed of innumerous substrates and with strong patchiness, and large perimeters, providing a great number of possible niches for invertebrates (BEISEL et al., 2000). In other words, the heterogeneity of microhabitats constitutes an important factor for enhancing biological diversity (MOLOZZI et al., 2011; HEINO, 2013). Thus, the use of artificial substrates is likely more effective for capturing particular groups of invertebrates. In addition, individuals being more dominant on a particular artificial substrate than on the stream bed may be due to the introduction of the new substrate an attractive resource. Preliminary studies on 
the composition of stream beds may be informative for choosing the most adequate substrate for sampling of the local community.

\section{References}

ALVES, R. G.; STRIXINO, G. The sampling of benthic macroinvertebrates using two different methods: Waiting Trays and an Ekman Collector. Acta Limnologica Brasiliensia, Botucatu, v. 15, n. 3, p. 1-6, 2003.

ARMitAGE, P. D.; CRANSTON P. S.; PINDER, L. C. V. The Chironomidae: the biology and ecology of non-biting midges. London: Chapman \& Hall, 1995. 538 p.

BEISEL, J. N.; MORETEAU, J. C.; USSEGLIO-POLATERA, P. The spatial heterogeneity of a river bottom: a key factor determining macroinvertebrate communities. Hydrobiologia, Brussels, v. 422/423, p. 163-171, 2000.

BENÔIT, H. P.; JOHNSTON, N. T.; PARKINSON, E. A.; POST, J. R. Colonization by lentic macroinvertebrates: evaluating colonization processes using artificial substrates and appraising applicability of the technique. Canadian Journal of Fisheries and Aquatic Sciences, Toronto, v. 55, p. 2425-2435, 1998.

BORKENT, A. The systematics and phylogeny of the Stenochironomus complex (Xestochironomus, Harrisius and Stenochironomus) (Diptera: Chironomidae). Memoirs of the Entomological Society of Canada, Ottawa, v. 128, p. 1-269, 1984. BRINKHURST, R. O.; MARCHESE, M. R. Guía para la identificación de Oligoquetos acuáticos continentals de sud y Centroamérica. Coleção Climax, n. 5. Santa Fe: Associación Ciencias Naturales del Litoral, 1989. 207 p.

CARVALHO, E. M.; UIEDA, V. S. Colonização por macroinvertebrados bentônicos em substrato artificial e natural em um riacho da Serra de Itatinga, São Paulo, Brasil. Revista Brasileira de Zoologia, Curitiba, v. 21, n. 2, p. 287-293, 2004.

CLAPCOTT, J. E.; BUNN, S. E. Can C4 plants contribute to aquatic food webs of subtropical streams? Freshwater Biology, London, v. 48, p. 1105-1116, 2003.

CORBI, J.; TRIVINHO-STRIXINO, S. Relationship between sugar cane cultivation and stream macroinvertebrate communities. Brazilian Archives of Biology and Technology, Curitiba, v. $51 \mathrm{n}$. 4, p. 769-779, 2008.

CORREIA, L. C. S.; TRIVINHO-STRIXINO, S. Chironomidae (Diptera) em substratos artificiais num pequeno reservatório: represa do Monjolinho, São Carlos, São Paulo, Brasil. Entomología y Vectores [online], Rio de Janeiro, v. 12, n. 2, p. 265-274, 2005.

COSTA, J. M.; DE SOUZA, L. O. I.; OLDRINI, B. B. Chave para identificação das famílias e gêneros das larvas conhecidas de Odonata do Brasil: comentários e registros bibliográficos. Publicações Avulsas do Museu Nacional, Rio de Janeiro, n. 99, p. 3-42, 2004.

CZERNIAWSKA-KUSZA, I. Use of artificial substrates for sampling benthic macroinvertebrates in the assessment of water quality of large lowland rivers. Polish Journal of Environmental Studies, Olsztyn, v. 13, n. 5, p. 579-584, 2004.

DOMÍNGUEZ, E.; FERNÁNDEZ, H. R. Guía para la determinación de los artrópodos bentônicos sudamericanos.
Tucumán: Universidad Nacional de Tucumán, Facultad de Ciencias Naturales e Instituto M. Lillo, 2004. 282 p

DOMÍNGUEZ, E.; HUBBARD, M. D.; MOLINERI, C.; NIETO, C.; PESCADOR, M. L. Aquatic biodiversity in Latin America: Ephemeroptera of South America. Vol. 2. Sofia-Moscow: Ed. Pensoft., 2006. 646 p.

DUDGEON, D.; WU, K. K. Y. Leaf litter in a tropical stream: food or substrate for macroinvertebrates? Archiv für Hydrobiologie, Stuttgart, v. 146, p. 65-82, 1999.

FENOGLIO S.; AGOSTA P.; BO, T.; CUCCO M. Field experiments on colonization and movements of stream invertebrates in an Apennine river (Visone, NW Italy). Hydrobiologia, Brussels, v. 474, n. 1/3, p. 125-130, 2002.

GONÇALVES, J. F.; CALLISTO, M.; FRANÇA, J.; REZENDE, R. $\mathrm{S}$. Invertebrate colonization during leaf processing of native, exotic and artificial detritos in a tropical stream. Marine and Freshwater Research, Collingwood, v. 63, p. 428-439, 2012.

GRAÇA, M. The role of invertebrates on leaf litter decomposition in streams - a review. International Review of Hydrobiology, Weinheim, v. 86, n. 4-5, p. 383-393, 2001.

HEINO, J. Environmental heterogeneity, dispersal mode, and cooccurrence in stream macroinvertebrates. Ecology and Evolution, Sheffield, v. 3, n. 2, p. 344-355, 2013.

JANKE, H.; TRIVINHO-STRIXINO, S. Colonization of leaf litter by aquatic macroinvertebrates: a study in a low order tropical stream. Acta Limnologica Brasiliensia, Botucatu, v. 19, n. 1, p. 109-115, 2007.

KOWNACKI, A. Taxocens of Chironomidae in streams of the Polish High Trata Mts. Acta Hydrobiologica, Cracóvia, v. 13, n. 4, p. 439-464, 1971.

LECCI, L. S.; FROEHLICH, C. G. Plecoptera. In: FROEHLICH, C. G. (Org.). Guia online: identificação de larvas de insetos aquáticos do estado de São Paulo. Available on: $<$ http://sites.ffclrp. usp.br/aguadoce/guiaonline>. Access: May 222007.

LEITE-ROSSI, L. A.; TRIVINHO-STRIXINO, S. Are sugar cane leaf-detritus well colonized by aquatic macroinvertebrates? Acta Limnologica Brasiliensia, Botucatu, v. 24, n. 3, p. 303-313, 2012.

MACKAY, R. J. Colonization by lotic macroinvertebrates: a review of processes and patterns. Canadian Journal Fisheries Aquatic Sciences, Toronto, n. 49, p. 617-628, 1992.

MOLOZZI, J.; ARAUJO, T. L. A.; CALLISTO, M.; FRANÇA, J. S.; HUGHES, R. M.; VIANA, T. H. Diversity of physical habitat and its relationship with benthic macroinvertebrates in urban reservoirs in Minas Gerais. Iheringia, Série Zoologia, Porto Alegre, v. 101, n. 3, p. 191-199, 2011.

NIESER, N.; DE MELO, A. L. Os heterópteros aquáticos de Minas Gerais. Guia introdutório com chave de identificação para as espécies de Nepomorpha e Gerromorpha. Belo Horizonte: Ed. UFMG. 1997. 180 p.

OLOMUKORU, J. O.; TOCHUKWU, O. C. N. Macro-invertebrate colonization of artificial substrata II: weeds and plant stems. Asian Journal of Plant Sciences, Lasani, v. 5, n. 6, p. 990-995, 2006.

ORTELI, B.; LACHAVANNE, J. B. The effects of shoot age on colonization of an emergent macrophyte (Typha latifolia) by macroinvertebrates. Freshwater Biology, London, v. 34, p. 421$431,1995$. 
PAULA, M. C.; FONSECA-GESSNER, A. A. Macroinvertebrates in low-order streams in two fragments of Atlantic Forest in different states of conservation, in the State of São Paulo (Brazil). Brazilian Journal of Biology, São Carlos, v. 70, n. 3, p. 899-909, 2010.

PASSOS, M. I. S.; FERREIRA Jr, N.; NESSIMIAN, J. L. Chaves para identificação dos gêneros de Elmidae (Coleoptera) ocorrentes no estado do Rio de Janeiro, Brasil. Revista Brasileira de Entomologia, Curitiba, v. 51, n. 1, p. 42-53, 2007.

PEPINELLI, M.; TRIVINHO-STRIXINO, S. Colonização de substratos artificiais de diferentes cores por imaturos de Simulium inaequale Paterson \& Shannon, 1927 (Diptera, Simuliidae). Entomología y Vectores, Rio de Janeiro, v. 9, n. 3, p. 349-357, 2002.

PEREIRA, D.; BERGONCI, P. E. A.; DOS SANTOS, C. P.; MANSUR, M. C. D.; OLIVEIRA, M. D.; VOLKMER-RIBEIRO, C. Colonização de substrato artificial por macroinvertebrados límnicos, no delta do rio Jacuí (RS, Brasil). Biotemas, Florianópolis, v. 23, n. 1, p. 101-110, 2010.

PES, A. M. O.; HAMADA, N.; NESSIMIAN, J. L. Chaves de Identificação de larvas para famílias e gêneros de Trichoptera (Insecta) da Amazônia Central, Brasil. Revista Brasileira de Entomologia, Curitiba, v. 49, n. 2, p. 181-204, 2005.

RAMSEYER, U.; MARCHESE, M. Leaf litter of Erythrina crista-galli L. (ceibo): trophic and substratum resources for benthic invertebrates in a secondary channel of the Middle Paraná River. Limnetica, Barcelona, v. 28, n. 1, p. 1-10, 2009.

RIBEIRO, L. O.; UIEDA, V. S. Estrutura da comunidade de macroinvertebrados bentônicos de um riacho de serra em Itatinga, São Paulo, Brasil. Revista Brasileira de Zoologia, Curitiba, v. 22, n. 3, p. 613-618, 2005 .

RIERADEVALL, M.; BONADA, N.; PRAT, N. Substrate and depth preferences of macroinvertebrates along a transect in a Pyrenean high mountain lake (Lake Redó, NE Spain). Limnetica, Barcelona, v. 17, p. 127-134, 1999.

RINCÓN, J.; MARTÍNEZ, I. Food quality and feeding preference of Phylloicus sp. (Trichoptera: Calamoceratidae). Journal of the North American Benthological Society, Lawrence, v. 25, n. 1, p. 209-215, 2006.

RINELLA, D. J.; FEMINELLA, J. W. Comparison of benthic macroinvertebrate colonizing sand, wood, and artificial substrates in a low gradient stream. Journal of Freshwater Ecology, Lund, v. 20, n. 2, p. 209-220, 2005.

ROQUE, F. O.; SIQUEIRA, T.; TRIVINHO-STRIXINO, S. Occurrence of chironomid larvae living inside fallen-fruits in Atlantic Forest streams, Brasil. Entomologia y Vectores, Rio de Janeiro, v. 12, n. 2, p. 275-282, 2005.
ROQUE, F. O.; TRIVINHO-STRIXINO, S. Four new species of Endotribelos Grodhaus, a common fallen fruit-dwelling chironomid genus in Brazilian streams (Diptera: Chironomidae: Chironominae). Studies on Neotropical Fauna and Environment, Tübingen, v. 43, n. 3, p. 191-207, 2008.

SAITO, V. S.; MAZÃO, G. R. Macroinvertebrates under stochastic hydrological disturbance in Cerrado streams of Central Brazil. Iheringia, Série Zoologia, Porto Alegre, v. 102, n. 4, p. 459-464, 2012.

SANSEVERINO, A.; NESSIMIAM, J. Habitat preferences of Chironomidae larvae in an upland stream of Atlantic Forest, Rio de Janeiro State, Brazil. Verhandunglen des Internationalen Verein Liminologie, Stuttgart, v. 26, p. 2141-2144, 1998.

SOUZA, A. H. F. F.; ABÍLIO, F. J. P.; RIBEIRO, L. L. Colonização e sucessão ecológica do zoobentos em substratos artificiais no açude Jatobá I, Patos - PB, Brasil. Revista de Biologia e Ciências da Terra, João Pessoa, v. 8, n. 2, p. 125-144, 2008.

STOCKLEY, R. A.; ORMOND, R. F. G.; OXFORD, G. S. Do invertebrates matter? Detrital processing in the River Swale-Ouse. Science of the Total Environment, Amsterdam, v. 210/211, p. 427-435, 1998.

TRIVINHO-STRIXINO, S. Ordem Diptera. Família Chironomidae. Guia de identificação de larvas. In: HAMADA, N.; NESSIMIAN, J. L.; QUERINO, R. B. (Org.). Insetos aquáticos na Amazônia brasileira: taxonomia, biologia e ecologia. Vo. 1. 1 ed. Manaus: Editora do INPA, 2014. p. 457-660.

TRIVINHO-STRIXINO, S.; STRIXINO， G. Chironomidae (Diptera) associados a troncos de árvores submersos. Revista Brasileira de Entomologia, Curitiba, v. 41, n. 2-4, p. 173-178, 1998.

VALENTE-NETO, F.; KOROIVA, R.; FONSECA-GESSNER, A. A.; ROQUE, F. O. The effect of riparian deforestation on macroinvertebrates associated with submerged woody debris. Aquatic Ecology, Heidelberg, DOI: 10.1007/s10452-015-9510-y, 2015.

WANTZEN, K. M.; PINTO-SILVA, V. Uso de substratos artificiais para avaliação do impacto do assoreamento sobre macroinvertebrados bentônicos em um córrego de cabeceira no Pantanal do Mato Grosso, Brasil. Revista Brasileira de Recursos Hídricos, Belo Horizonte, v. 11, p. 99-107, 2006. 